\title{
Morphological and quantitative analysis of cerebellar cortical cells in Alzheimer's disease
}

\author{
Tomasz Stępień, Teresa Wierzba-Bobrowicz, Eliza Lewandowska, Grażyna Szpak \\ Department of Neuropathology, Institute of Psychiatry and Neurology, Warsaw, Poland
}

\begin{abstract}
Alzheimer's disease $(A D)$ is a neurodegenerative amyloid disease, although a great deal of research has been done, its aetiology is still unknown. In Khachaturian's hypothesis on the involvement of calcium in the aetiology of Alzheimer's disease, particular attention is paid to the disorder of calcium metabolism. Ludo van Bogaert, describing $A D$, has drawn attention to the presence of a multi-system damage to the brain and described four forms of the disease, including two cerebellar types: cerebellar-pyramidal and cerebellar. The aim of our study was to analyze the expression of calcium-binding proteins (calbindin, calretinin, parvalbumin) in cortical neurons of the cerebellum in patients diagnosed with Alzheimer's disease (experimental group) and in a control group (patients without Alzheimer's disease). We performed the quantitative analysis of the density of Purkinje cells and Bergmann glial cells in the cerebellar cortex. We observed weak immunoreaction with a calretinin antibody in Lugaro cells, and with parvalbumin in Purkinje cells in the experimental group. A weaker expression of calcium-binding proteins in the experimental group may indicate the disturbance of the transport and buffering of intracellular $\mathrm{Ca}^{2+}$ levels. The quantitative analysis showed that the density of Bergmann glial cells was higher in the experimental group. Our study suggests the disturbance of calcium metabolism in Alzheimer's disease.
\end{abstract}

Key words: Alzheimer's disease, cortical neurons of cerebellum, calcium-binding proteins.

\section{Introduction}

Alzheimer's disease (AD) is a neurodegenerative amyloid disease, although a great deal of research has been done, its aetiology is still unknown. It is known that $A D$ is associated with the impairment of certain metabolic pathways and its incidence increases with age. In Khachaturian's hypothesis on the involvement of calcium in the aetiology of Alzheimer's disease, particular attention is paid to the disorder of calcium metabolism [25]. $\mathrm{Ca}^{2+}$, a secondary signal molecule of a properly functioning cell located in the cytoplasm and the light of the endoplasmic reticulum (ER), is responsible for internal and external communication service. The concentration of $\mathrm{Ca}^{2+}$ in the endoplasmic reticulum is 1000 times higher than in the cytoplasm. During activation, $\mathrm{Ca}^{2+}$ is released from the endoplasmic reticulum to the cytoplasm through inositol 1,4,5-trisphosphate $\left(\mathrm{IP}_{3}\right)$ receptors and ryanodine receptors (RyR) involved in the internal induction of apoptosis [6]. There is a group of calcium-binding proteins (CaBP), strongly evolutionarily conserved. 
CaBPs are divided into two groups: proteins binding and buffering $\mathrm{Ca}^{2+}$ levels in the cell (parvalbumin, calretinin and calbindin) and $\mathrm{CaBP}$ for $\mathrm{Ca}^{2+}$ translocation to the cell, participating in the transduction signal (calmodulin). Calbindin-D28k appears first as early as at 4-5 hbd, but not later than the expression of parvalbumin occurs in the development process. CaBPs play a neuroprotective role and via $\mathrm{Ca}^{2+}$ binding inhibit caspase activity in the cell. It is also suggested that CaBPs are involved in the regulation of cell division and maturation of neurons in the cerebellum [3,29,31,55].

During the course of Alzheimer's disease the functions of the brain undergo different forms of gradual damage, causing an insidious and difficult to capture onset of the disease. Ludo van Bogaert, describing AD, has drawn attention to the presence of a multi-system damage to the brain and described four forms of the disease, including two cerebellar types: cerebellarpyramidal and cerebellar [5]. Despite the features of the cerebellar cognitive-affective syndrome present in $A D$, other regions of the brain, including cerebellum, are collected optionally for neuropathological diagnosis.

The cerebellum is also linked with the structures associated with cognitive and behavioural functions: dorsal-lateral prefrontal cortex, medial frontal cortex, parietal lobe and the upper part of the temporal lobe, anterior cingulate, and the rear part of the hypothalamus [11]. Noradrenergic fibers, serotonergic and dopaminergic nuclei of the brainstem and cholinergic fibres reach the cerebellum. Noradrenaline facilitates learning processes occurring in the cerebellar cortex. The dorsal and ventral parts of the locus coeruleus are the source of noradrenergic fibres reaching all the layers of the cerebellar cortex $[14,26]$. Serotonin controls the response within the feedback loop involved in learning processes. Serotonergic fibres form a dense network of the cerebellar cortex, especially in Purkinje cells and granular layer $[22,23,34]$. Dopamine facilitates learning associated with intentional responses [47] through a cascade of CAMP and dopamine and cyclic AMP regulated phospho-protein-32 (DARP-32), by modifying the sensitivity of Purkinje cells GABA [21]. Acetylcholine induces a strong and long-lasting response of Purkinje cells to glutamate, strengthening the synaptic transmission between Purkinje and granular cells [2,15].

The cerebellar cortex consists of three layers: an outer molecular layer, a middle Purkinje cell layer (ganglionic layer) and an inner granular layer. In the molecular layer two groups of interneurons are distinguish- ed: stellate and basket cells. A middle Purkinje cells layer consists of neurons about $70 \mu \mathrm{m}$ in diameter. Purkinje cells are involved in many learning and memory processes, as well as in the process of neurons migration $[47,48]$. Purkinje cells comprise all known types of inositol triphosphate $\left(\mathrm{IP}_{3}\right)$ receptors, which facilitate $\mathrm{Ca}^{2+}$ transportation, glutamatergic receptors, and glutamic acid decarboxylase (GAD) protein, an enzyme involved in the GABA metabolism, and cholinergic receptors implicated in the process of memory renewal [47]. In the ganglionic layer, besides Purkinje cells, there are Bergmann glial cells, a group of specialized astrocytes involved in synaptogenesis and signal transduction between Purkinje cells $[7,33,36]$. Of the four known subtypes of glutamate transporters, glutamate aspartate transporter (GLAST) and glutamate transporter-1 (GLT-1) are characteristic for astrocytes, and their expression occurs mainly in the cerebellum. Bergmann glial cells are engaged in the process of neurotransmitter amino group removal from the synaptic space $[45,50]$.

In the granular layer, four types of interneurons are distinguished. Golgi small cells (granular cells) less than $6 \mu \mathrm{m}$ in diameter, which form numerous synapses with Purkinje cell dendrites are thought to be the smallest human brain cells. Golgi large cells (size of 10-20 $\mu \mathrm{m}$ ) are involved in the transmission of cortical feedback [27]. They form synapses with granular cells and molecular layer cells. Lugaro cells (size of 10-20 $\mu \mathrm{m}$ ) occur in the upper part of the granular layer and form links with Purkinje cells, Golgi large cells, stellate and basket cells [30]. On account of their structure two types of Lugaro cells, two- and three-armed, are known [35]. Finally, there is one more type of cells, unipolar brush cells (UBC), a group of small interneurons (size of 8-14 $\mu \mathrm{m}$ ), primarily regarded as a subclass of Golgi large cells characterized by the structure similar to a brush $[10,13,20,36]$.

The aim of our study was to analyze the expression of CaBPs (calbindin, calretinin, parvalbumin) in cortical neurons of the cerebellum in patients diagnosed with Alzheimer's disease and to perform the quantitative analysis of the density of Purkinje cells and Bergmann glial cells in the cerebellar cortex.

\section{Material and methods}

The study material was examined with the use of light microscopy. The control group comprised cerebellar fragments derived from 15 patients (mean 75.67 
years) who showed neither Alzheimer's disease nor extensive neuropathological changes in the brain, especially in the cerebellum, and died from other diseases (e.g. cardio-pulmonary failure, heart attack, ischemic stroke). The experimental group consisted of cerebellar fragments derived from 13 patients (mean 76.77 years) diagnosed with Alzheimer's disease lasting not longer than 10 years. After autopsy all cerebellar fragments were fixed in formalin, embedded in paraffin, and stained with haematoxylineosin, cresyl violet and Klüver-Barery to identify morphology.

The specimens of cerebellum were stained immunohistochemically with antibodies calbindin D-28k (CB) (Sigma, 1 : 2500), calretinin (CR) (DAKO, 1 : 75), parvalbumin (PV) (Sigma, $1: 2000$ ), and glial fibrillary acidic protein (GFAP) (Leica, $1: 100)$.

The density of Purkinje cells and Bergmann glial cells, in the region of cortex declive surface of $14.6 \mathrm{~mm}^{2}$, was analyzed in the experimental and control groups (Fig. 1). Preparations were analyzed in Zeiss Axiophot light microscope and then recorded by a set of scanning, including a table with unit labour Märzhäuser LUDL and KS RUN library. STATISTICA 9 was employed to analyze the results obtained. Spearman and Pear- son's correlation tests for the density of Purkinje and Bergmann glial cells, as well as analysis of variance ANOVA were performed.

\section{Results}

\section{Molecular layer}

In the material derived from patients not diagnosed with Alzheimer's disease (control group) stellate cells staining in hematoxylin-eosin (H\&E) were observed in the molecular layer at a height of roughly $2 / 3$ of the Purkinje cell layer. They were characterized by the scant cytoplasm and dark nucleus. In staining with parvalbumin antibody only a weak immunohistochemical (IHC) reaction was observed (Table I) (Fig. 2A). In the patients with diagnosed Alzheimer's disease (experimental group) stellate cells, observed in the molecular layer, did not show morphological differences. In IHC response a similar, equally $\mathrm{IHC}$ reaction with parvalbumin was noted (Fig. 2B). In light microscopy, H\&E staining basket cells formed a group of cells with oval nuclei, located at a height of $1 / 3$ width of the molecular layer above the Purkinje cells layer. In the control group, $\mathrm{H} \& \mathrm{E}$ staining basket cells showed a well pigment-
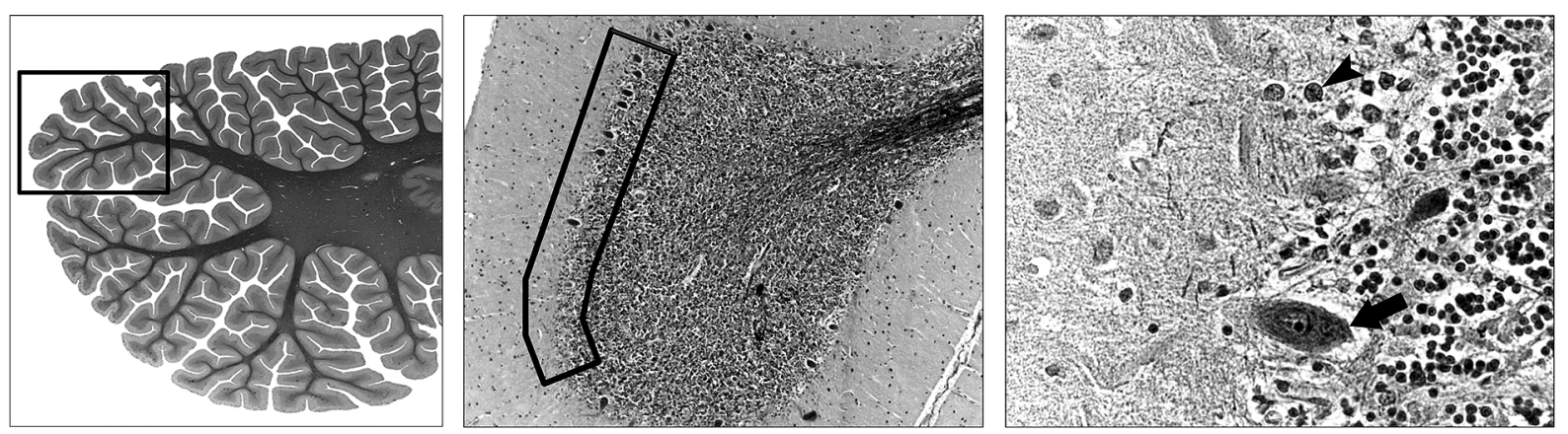

Fig. 1. Scheme of quantitative analysis of cerebellar cortex declive surface. Purkinje cells (arrow), Bergmann glial cells (head arrow).
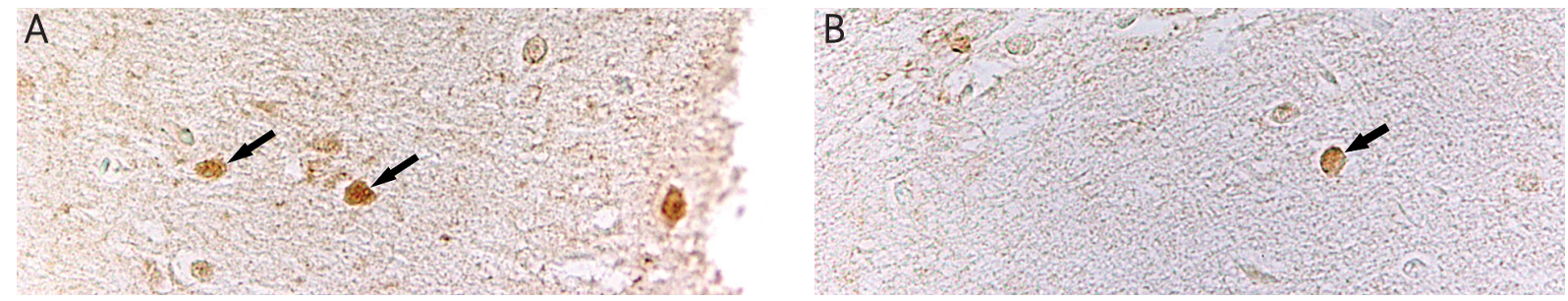

Fig. 2. A) Control group. Stellate cells of the cerebellar cortex (arrows). Parvalbumin. Magnification $\times 400$.

B) Alzheimer's disease group. An IHC reaction in stellate cells (arrow). Parvalbumin. Magnification $\times 400$. 

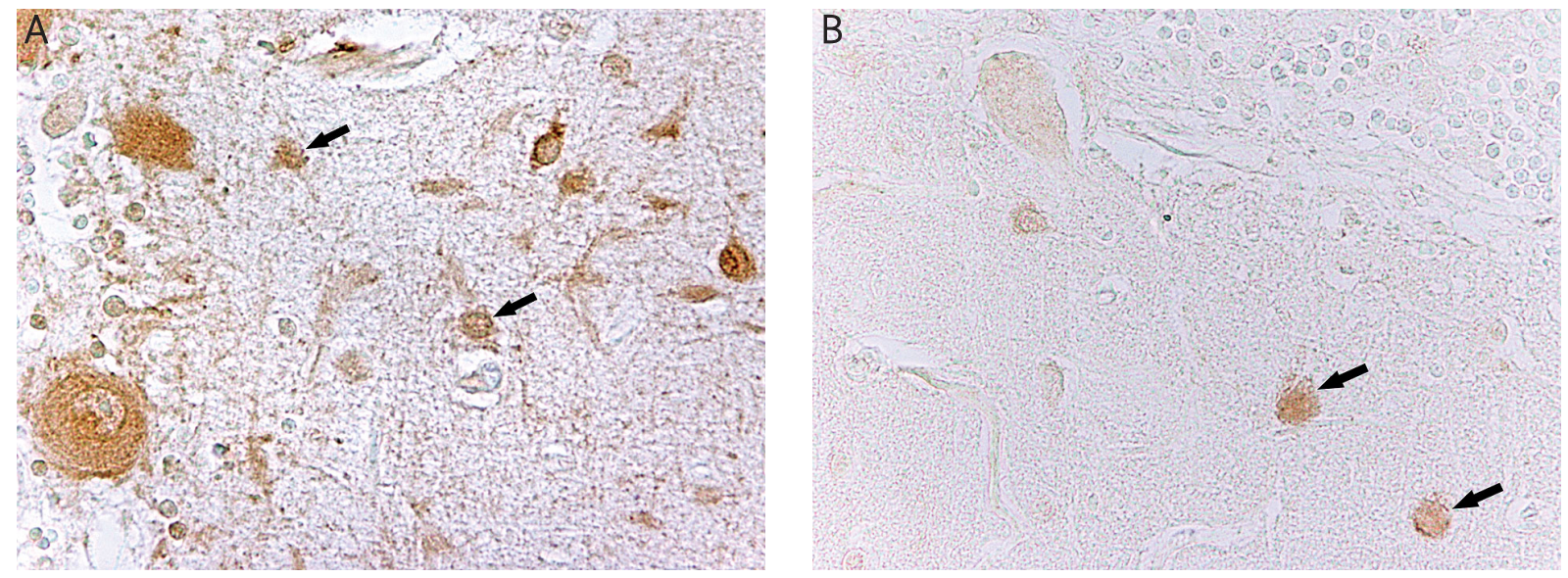

Fig. 3. A) Control group. Parvalbumin: a slight IHC reaction in basket cells of the cerebellar cortex (arrows). Magnification $\times$ 400. B) Alzheimer's disease group. Parvalbumin: an IHC reaction in basket cells (arrows). Magnification $\times 400$.

ed, sparse, light pink cytoplasm. In the experimental group, a picture of the basket cell morphology did not differ from that of caged cells in the control group. In the control group, basket cells showed a very clearly marked reaction only with parvalbumin antibody (Fig. 3A). The basket cells showed neither reaction with calbindin-D28k nor with calretinin antibodies (Table I). In the experimental group, a very weak IHC reaction with parvalbumin was observed only in single basket cells (Fig. 3B).

\section{Ganglionic layer/Purkinje cells layer}

In the control group, Purkinje cells in H\&E staining showed a well preserved shape and uniformly stained bright pink cytoplasm. A fragment of axon and single dendrites could be sometimes seen. In the control group, uniformly and strongly labelled perikaryon and the Purkinje cell axon were observed in calbindinD28k labelling (Fig. 4A). In the experimental group, the $I H C$ reaction with calbindin-D28k labelling was as strong as that in the control group. The reaction

Table I. Immunohistochemical reaction in cerebellar cortical cells in control and experimental groups (AD).

\begin{tabular}{|c|c|c|c|c|c|c|c|c|}
\hline \multirow[t]{3}{*}{ Cerebellar cortical cells } & \multicolumn{8}{|c|}{ Antibody } \\
\hline & \multicolumn{2}{|c|}{ Calbindin D-28k (CB) } & \multicolumn{2}{|c|}{ Calretinin (CR) } & \multicolumn{2}{|c|}{ Parvalbumin (PV) } & \multicolumn{2}{|c|}{ GFAP } \\
\hline & Control & $A D$ & Control & $A D$ & Control & $A D$ & Control & $A D$ \\
\hline Stellate cells & $\mathrm{N}$ & $\mathrm{N}$ & $\mathrm{N}$ & $N$ & $P$ & $P$ & $N$ & $\mathrm{~N}$ \\
\hline Basket cells & $\mathrm{N}$ & $\mathrm{N}$ & $\mathrm{N}$ & N & $P$ & $S-L$ & $\mathrm{~N}$ & $\mathrm{~N}$ \\
\hline Purkinje cells & $P$ & $P$ & N & N & S-P & $S-L$ & $\mathrm{~N}$ & $\mathrm{~N}$ \\
\hline Lugaro cells & $\mathrm{N}$ & $\mathrm{N}$ & $P$ & $\mathrm{~L}$ & $\mathrm{~N}$ & $\mathrm{~N}$ & $\mathrm{~N}$ & $\mathrm{~N}$ \\
\hline Golgie small cells & $\mathrm{N}$ & N & N & N & N & $\mathrm{N}$ & $\mathrm{N}$ & N \\
\hline Golgie large cells & $\mathrm{N}$ & $\mathrm{N}$ & $P$ & $P$ & $\mathrm{~N}$ & $\mathrm{~N}$ & $\mathrm{~N}$ & $\mathrm{~N}$ \\
\hline Unipolar brush cells & N & $\mathrm{N}$ & $P$ & $P$ & $\mathrm{~N}$ & $\mathrm{~N}$ & $\mathrm{~N}$ & $\mathrm{~N}$ \\
\hline Bergmann glial cells & $\mathrm{N}$ & $\mathrm{N}$ & $\mathrm{N}$ & $N$ & $\mathrm{~N}$ & $\mathrm{~N}$ & S-P & S-P \\
\hline
\end{tabular}

$N$ - negative, $P$ - positive, $L$ - low sensitivity, $S$ - some of cells 

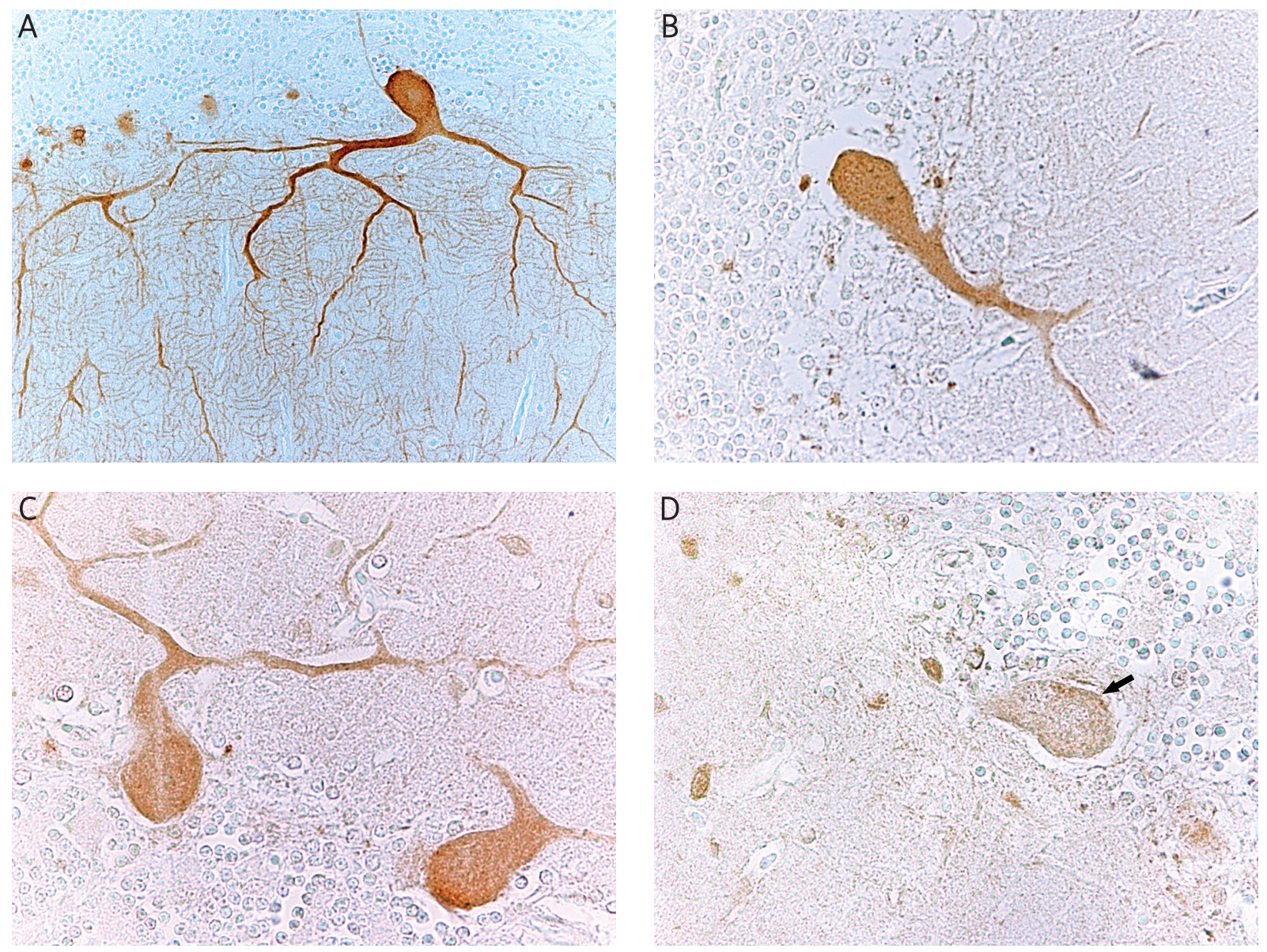

Fig. 4. A) Control group. Calbindin: a strong IHC reaction in Purkinje cells and their processes. Magnification $\times$ 400. B) Alzheimer's disease group. Calbindin: a strong reaction in Purkinje cells and a weak reaction in their processes. Magnification $\times 400$. C) Control group. Parvalbumin: a strong reaction in Purkinje cells and a weaker reaction in their axon. Magnification $\times 400$. D) Alzheimer's disease group. Parvalbumin: a weaker IHC reaction in Purkinje cells (arrow). Magnification $\times 400$.

occurred in perikaryon and Purkinje cell axons. An IHC reaction with calbindin-D28k was observed in all Purkinje cells (Fig. 4B). In calretinin labelling no IHC reaction in Purkinje cells was observed in any of the groups under study. In parvalbumin labelling a stronger immunohistochemical reaction in perikaryon and a weaker reaction in the Purkinje cells axon were found (Fig. 4C). In the experimental group, H\&E staining, showed in some cases blurred boundaries of Purkinje cells and the cytoplasm stained lighter compared with the control group. In parvalbumin labelling a weak IHC reaction in axon and perikaryon was revealed (Table I). Relatively small amounts of Purkinje cells were found in both study groups (Fig. 4D).

In the control group, Bergmann glial cells placed near the Purkinje neurons were observed in both $\mathrm{H} \& \mathrm{E}$ staining and in the reaction with GFAP antibody. In H\&E staining Bergmann glial cells were visible as a dispersed chromatin nuclei sometimes with a narrow seam of cytoplasm with clearly visible nucleoli without visualization of the processes. In the reaction with GFAP antibody, Bergmann glial cells became visible as a bright nucleus and a few thick insets, laying parallel to the layers of web press but also running perpendicular to the surface of the cerebellar cortex. Not all cells with Bergmann glial morphology, showed a positive reaction with GFAP antibody (Fig. 5A). The cellular nuclei were slightly enlarged and brighter. In the reaction with GFAP antibody only single cells showed a positive reaction (Table I). Gliofilaments, showing a positive reaction with GFAP antibody were mostly in short, thickened glial processes (Fig. 5B). 

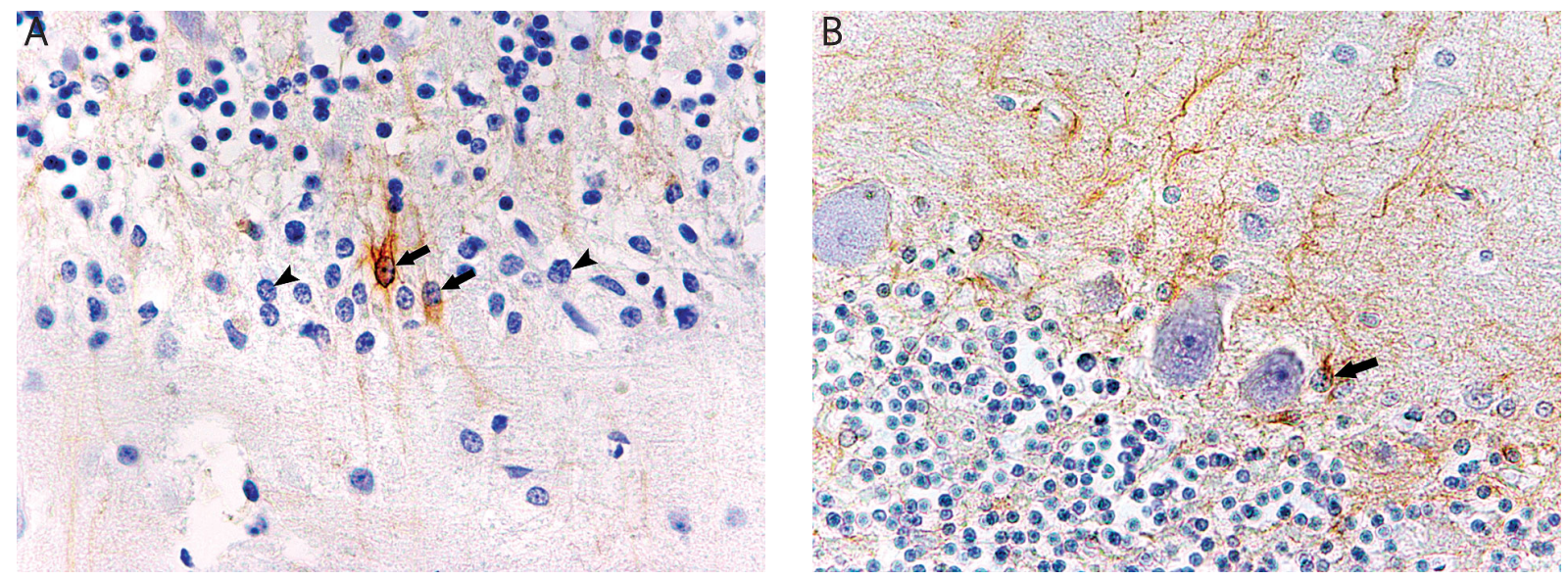

Fig. 5. A) Control group. Bergmann glial cells of the cerebellar cortex with an IHC reaction (arrows) and without immunoreaction (head arrows). GFAP. Magnification $\times 400$. B) Alzheimer's disease group. A GFAP positive reaction in Bergmann glial cells with thickened glial processes (arrow). Magnification $\times 400$.

\section{Granular layer}

In the control group, H\&E stained large Golgi cells did not exhibit characteristic features that allow to distinguish them from UBCs. In the control group, calretinin-labelled large Golgi cells showed a positive reaction in perikaryon (Fig. $6 \mathrm{~A}$ ). In the experimental group, the $\mathrm{IHC}$ reaction intensity was comparable to the response observed in the control group (Fig. 6B). In the control group, small Golgi cells in the granular layer formed a well-distinguished group of rather evenly distributed neurons. In the H\&E staining, this group was characterized by a dark round nucleus and almost invisible cytoplasm. We also observed decreased density of small Golgi cells. No positive $\mathrm{IHC}$ reactions with calbindin-D28k, calretinin or parvalbumin antibodies were observed. In the control group in H\&E, cresyl violet and Klüver-Barrera staining Lugaro cells were characterized by a horizontal arrangement of the granular layer of cerebellar cortex under the Purkinje cells layer. In the control group, in the $\mathrm{IHC}$ reaction with calretinin, Lugaro cells showed a calretinin-positive reaction, visible in the cytoplasm of neurons and in the processes of both cellular type (Fig. 7A). In the experimental group, an expression of calretinin was significantly weaker than that in the control group (Fig. 7B). In the control group, H\&E stained UBCS did not exhibit characteristic features that allow to distinguish
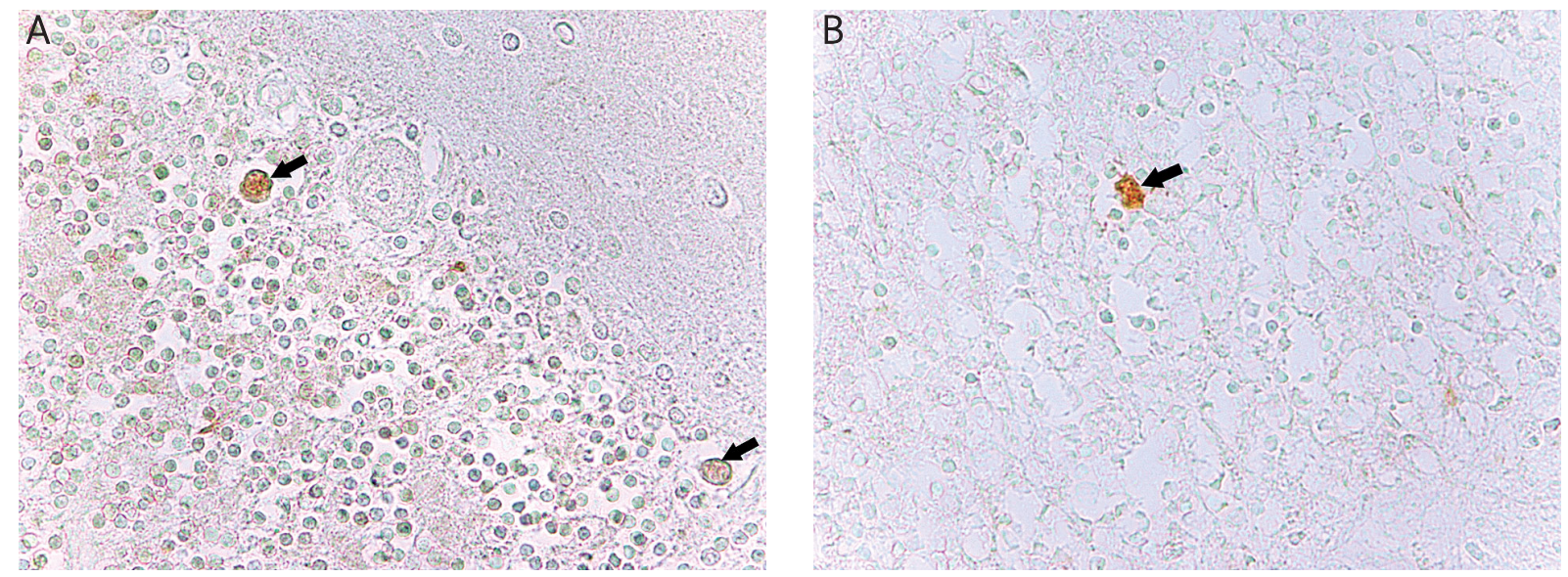

Fig. 6. A) Control group. Calretinin: a positive reaction in Golgi cells of the cerebellar cortex (arrows). Magnification $\times$ 400. B) Alzheimer's disease group. Calretinin: a reaction in Golgi cells (arrow). Magnification $\times 400$. 

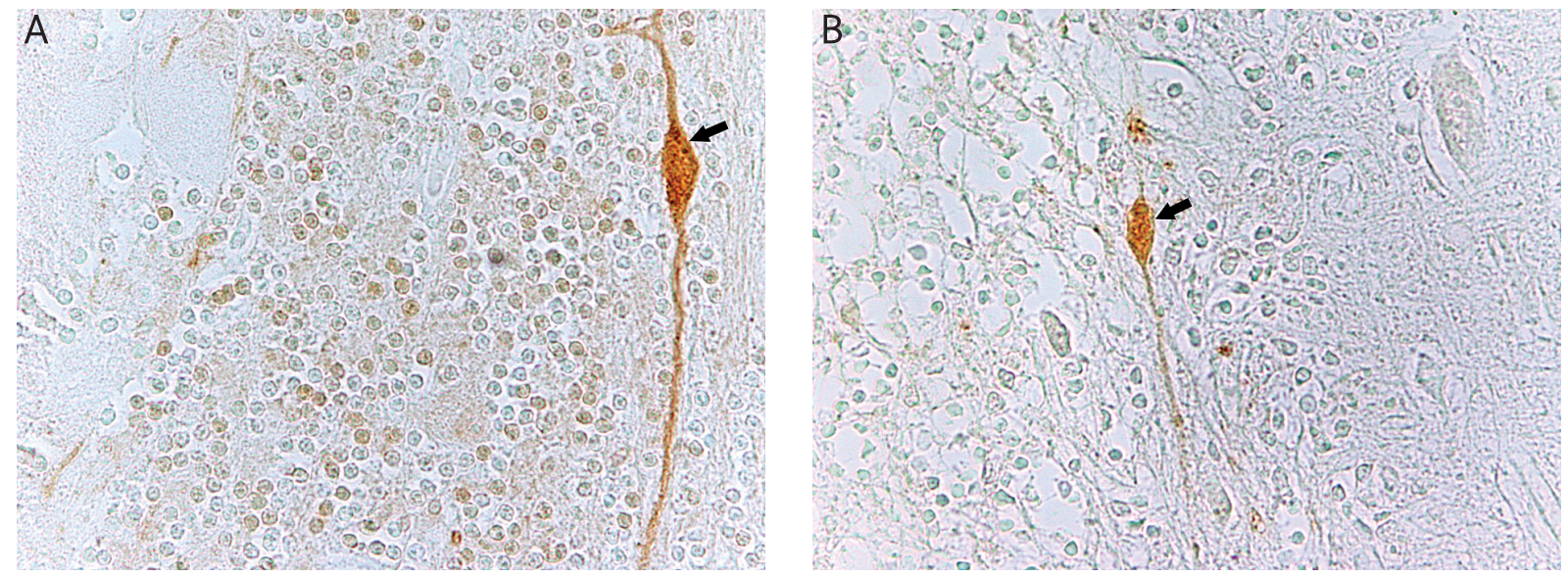

Fig. 7. A) Control group. Calretinin: an intense reaction observed in Lugaro cells (arrow). Magnification $\times$ 400. B) Alzheimer's disease group. Calretinin: a weak reaction IHC in Lugaro cells of the cerebellar cortex (arrow). Magnification $\times 400$.

them from Golgi large cells (Table I). In both study groups, UBCs showed the same reaction with calretinin antibody in the neuron cytoplasm and axon initial segments (Figs. 8A and B).

\section{Quantitative analysis}

The density of Purkinje cells and Bergmann glial cells in the region of cortex declive surface of $14.6 \mathrm{~mm}^{2}$ were analyzed in both study groups. Due to aging changes, the experimental and control groups were divided into two age groups, under $80(<80)$ and over $80(\geq 80)$ years of age and in the experimental group, the disease duration was less than 10 years ( $<10$ years). Aver- age density of Purkinje cells in cerebellar cortex was $9.33 \pm 2.42$ and $9.11 \pm 2.07$ in the experimental group and control group, respectively. Average density of Purkinje cells in the control subgroup was $9.37 \pm 1.94(<80)$ and $8.73 \pm 2.39(\geq 80)$ and in experimental subgroups, it was $9.75 \pm 2.12(<80)$ (Fig. 9) and $8.85 \pm 2.86(\geq 80)$ (Fig. 10).

Average density of Bergmann glial cells in the cerebellar cortex was $72.10 \pm 32.11$ and $58.49 \pm 14.09$ in the experimental group and the control group, respectively. Average density of Bergmann glial cells in the experimental subgroups was $81.27 \pm 39.22(<80)$ and $61.39 \pm 19.33(\geq 80)$ and in the control subgroups it was $59.02 \pm 16.93(<80)$ and $57.69 \pm 9.78(\geq 80)$.
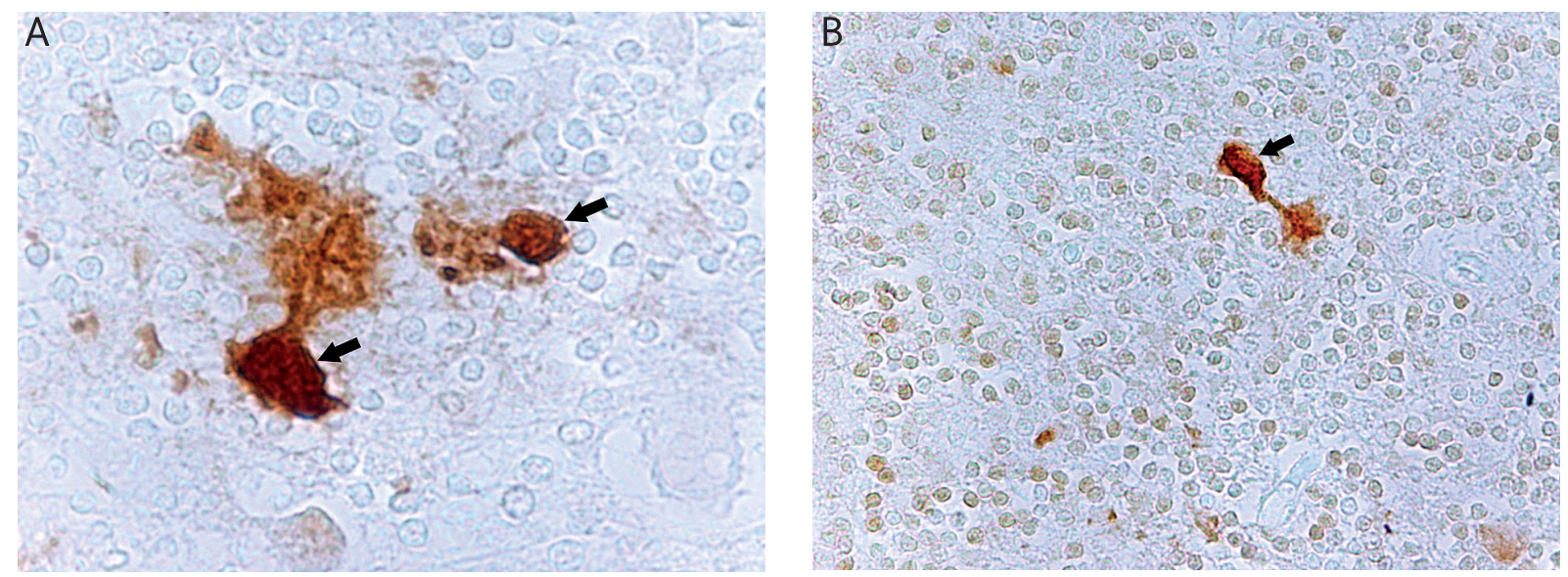

Fig. 8. A) Control group. A very intense calretinin reaction observed in unipolar brush cells and their processes (arrows). Magnification $\times 630$. B) Alzheimer's disease group. A comparable calretinin IHC reaction in unipolar brush cells to the control group (arrow). Magnification $\times 400$. 


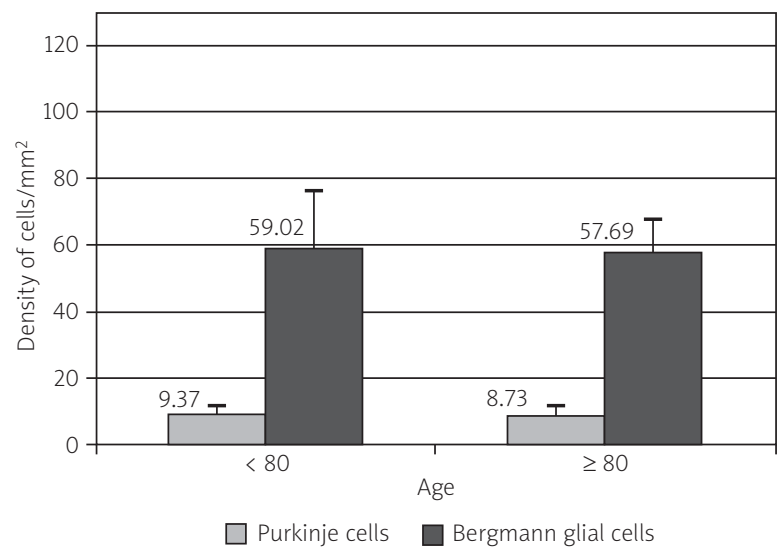

Fig. 9. Average value density of Purkinje cells and Bergmann glial cells in the cerebellar cortex in the control group below 80 years $(<80)$ and over 80 years $(\geq 80)(p=0.05)$.

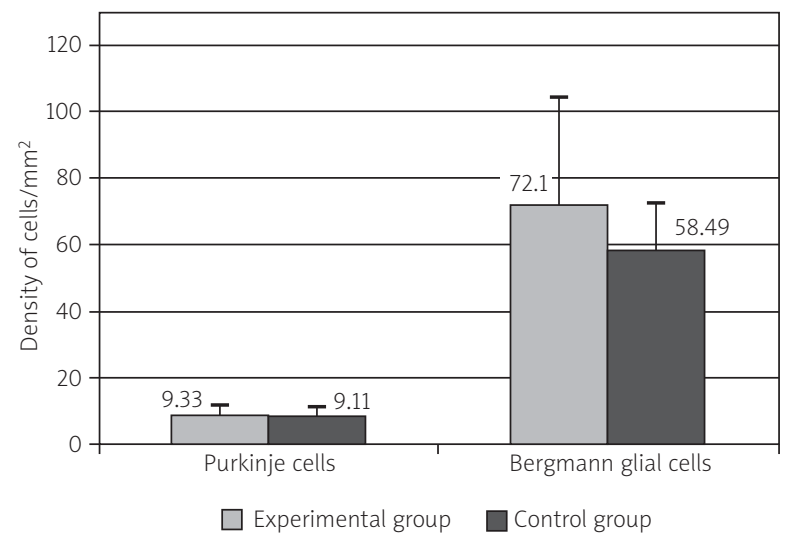

Fig. 11. Average value density of Purkinje cells and Bergmann glial cells in the cerebellar cortex in the control and experimental group ( $p=0.05)$.

The analysis of the density of Purkinje and Bergmann glial cells showed slightly higher values in the experimental group; on average there were 6.4 Bergmann glial cells per one Purkinje cell in the control group and 7.7 cells in the experimental group. The results of the quantitative analysis showed slight differences in the density of Purkinje cells and Bergmann glial cells in the cortex of the cerebellum between the study groups. The relationship between the density of Purkinje cells, Bergmann glial cells and age (Spearman and Pearson correlation tests) showed no statistically significant differences $(p=0.05)$ between the groups and within them. Testing the hypothesis of homogeneity of variance (Levene's test) indicated that the assumption of homogeneity of

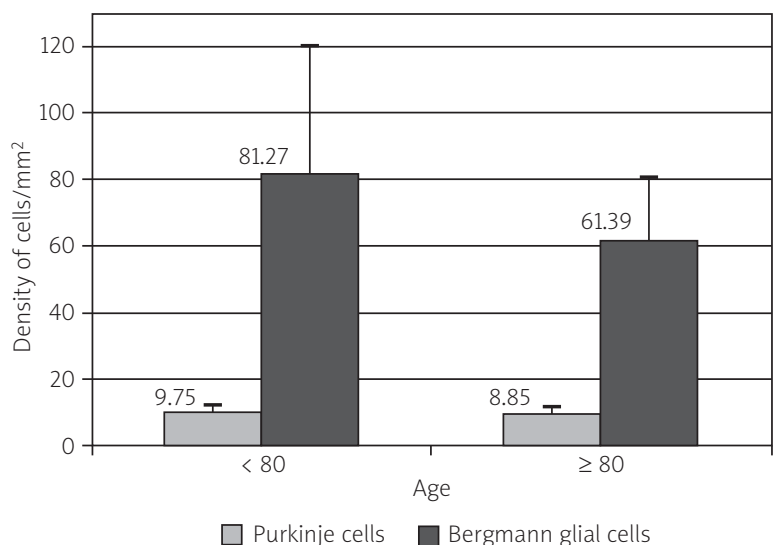

Fig. 10. Average value density of Purkinje cells and Bergmann glial cells in the cerebellar cortex in the experimental group below 80 years $(<80)$ and over 80 years $(\geq 80)(p=0.05)$.

variance was satisfied only for Bergmann glial cells (0.918). However, the analysis of variance (ANOVA) for univariate classification did not reveal any statistically significant differences (0.841) in the Bergmann glial cell density between the groups and within them.

\section{Discussion}

The changes in the Purkinje cells observed in the experimental group occur in the blurred boundaries of neurons and brighter, homogeneous staining of the cytoplasm. This type of morphological changes, observed in light microscopy, has been described as a disease of non-specific mixing degeneration of neurons [12]. This type of neuronal degeneration results most frequently from ischemic/hypoxic neurons and concerns Purkinje cells usually accompanied by Bergman glial cells proliferation and microglia. The quantitative analysis showed that the ratio of Purkinje cells to Bergmann glial cells was higher in the experimental group than in control group and amounted to 7.7 and 6.4 , respectively. Similar observations were described by other authors [16,39].

The fact that there were no differences in calbindin-28Dk expression in Purkinje cells in both groups does not confirm the reports on the neuroprotective role of calbindin-28Dk $[17,19]$. None of the study groups showed differences in the intensity of calretinin reaction in $U B C$, either in perikaryon neurons, initial segments of axon or large Golgi cells of the granular layer. In the experimental group, a significantly weaker $\mathrm{IHC}$ reaction in Lugaro cells than in the control group 
was observed. Despite conflicting reports on the calretinin expression in the ganglionic layer, we observed no $\mathrm{IHC}$ reaction in Purkinje cells [41,46]. However, this situation can be explained by the fixation procedure and conduct of the material, which caused damage to the less stable calretinin domain in Purkinje cells (Table I) [40].

A positive reaction with the antibody against parvalbumin, without changed expression intensity in both study groups was observed in neurons of molecular layers in stellate cells, while the weakening of the reaction in the basket cells and Purkinje cells was found in the experimental group. In Purkinje cells there are all known types of $\mathrm{IP}_{3}$ receptors [18]. Parvalbumin plays an important role in the transport and buffering of intracellular $\mathrm{Ca}^{2+}$ levels. Interacting with $\mathrm{IP}_{3}$ and RyR receptors, it regulates the flow of $\mathrm{Ca}^{2+}$ from the endoplasmic reticulum. A weaker expression of parvalbumin may indicate the disturbance of this mechanism.

A GFAP expression was observed in some Bergmann glial cells. Due to a small amount of fibrillary acidic protein, not all Bergmann glial cells were labelled with GFAP. Bergmann glial cells are involved in signal transduction between Purkinje cells $[32,33,36]$. Astrocytes play an important role in the removal of amino residues of neurotransmitters from synaptic space. Of the four known subtypes of glutamate transporters, GLAST and GLT-1, are characteristic for astrocytes, and their expression occurs mainly in the cerebellum, in the Bergmann glial cells $[45,50]$. The GLAST transporter is involved in transformation of the dendritic tree from the multi- to single-pole changes Purkinje cells [52]. There are reports on the increased degeneration of granular cells and Purkinje cells correlated with the reduced expression of GLAST [9] so that the protective role of Bergmann cells and their involvement in the protection of neurons against glutamate toxic effects has increased $[43,44,51]$. Studies carried out on GLAST $^{-/}$mice showed an impaired motor function and an increased susceptibility to cerebellar injury [53]. This can be explained by the occurrence of cerebellar ataxia in Alzheimer's patients which can be caused by the damage to GLAST transporter and its reduced expression. It is likely that the death of neurons, $\beta$-amyloid cytotoxicity and atrophy of astrocytes, make it more difficult to capture amino residues of alternating glutamate providing a complete picture of the pathomechanism of Alzheimer's disease [42].

In the study material, histological staining revealed a slight increase in Bergmann glial cell density and a brighter nuclear chromatin. Thus, it appears that this pathomorphological change in Bergmann glial cells, in the pool of star-shaped glial cells probably indicates pathognomic changes of Alzheimer's disease accompanied by astroglia [37,42]. In Alzheimer's disease pathomorphological changes in astrocytes located around senile plaques in perivascular astroglia, as well as in other forms of neuroglia are described. It becomes even more clear that astroglia are actively involved in the pathogenesis of Alzheimer's disease. In astrocytes apolipoprotein E (ApoE) is synthesized, as well as proinflammatory proteins and a form of the enzyme induction of nitric oxide synthase (NOS) are produced. These compounds are implicated in the pathomechanism of $A D$ development [56]. In the brains derived from the patients of the experimental group, a decreased density of Golgi small cells in the granular layer was also observed, however, it was not subjected to the quantitative analysis. The atrophy of the granular layer is usually described in paraneoplastic syndromes, alcohol encephalopathy, but it also occurs in the ischemic/hypoxic brain [12,28,38]. In Alzheimer's disease atrophy of the cerebellar vermis, atrophy of the Purkinje cells and gliosis in the molecular layer have also been reported [49]. In patients with AD advanced stages, some authors have noted the reduction of Purkinje cells up to $32 \%$ [54].

The results of the quantitative analysis show a higher density of Purkinje cells in the cerebellar cortex in patients below 80 years of age in both study groups (Figs. 9 and 10). This may indicate that in patients aged under 80 years, changes in the density of Purkinje cells did not produce the picture of progressive pathology in any of the study groups. The reduced Purkinje cell density in patients over 80 years of age in both groups may indicate progressive degenerative processes due to physiological aging and also in the mechanism of AD development. Analyzing the density of Purkinje and Bergmann glial cells, one should remember about cerebellar progressive atrophy in Alzheimer's disease, frequently reported in the literature, which can affect the density of both types of cells $[1,4,54]$. Purkinje cells are particularly sensitive, they may die in many pathologies and normal aging. It could be explain why we did not observe any changes in the density of Purkinje cells between the control and experimental groups. The analysis of Purkinje cell density in the experimental and control groups did not show statistically significant differences (Fig. 11). The increased density of Bergmann glial cells in the 
patients below 80 years of age of both study groups can imply a protective role of protoplasmic glial cells. The correlation between the occurrence of fronto-temporal dementia and increased gliosis was also observed [8]. It was found that in early stages of fronto-temporal dementia, the amount of cortical astroglia may be four or even five times higher in the experimental group than in controls [24]. This may evidence the protective role of Bergmann glial cells involved in the process of removing toxic glutamate residues. In view of numerous clinical symptoms, indicating the signs of the cerebellar cognitive-affective syndrome, the results of these studies suggest that the diagnosis of Alzheimer's disease should be supplemented by the neuropathological analysis of the cerebellum.

\section{References}

1. Andersen BB, Gundersen HJ, Pakkenberg B. Aging of the human cerebellum: a stereological study. J Comp Neurol 2003; 466: 356-365.

2. Andre P, Pompeiano O, White SR. Activation of muscarinic receptors induces a long-lasting enhancement of Purkinje cell responses to glutamate. Brain Res 1993; 617: 28-37.

3. Andressen C, Blümcke I, Celio MR. Calcium-binding proteins: selective markers of nerve cells. Cell Tissue Res 1993; 271: 181-208.

4. Barclay LL, Brady PA. Cerebellar atrophy as a CT marker for mixed dementia. Biol Psychiatry 1992; 31: 520-524.

5. Bogaert van L, Maert M, de Smedt E. Sur les formes familiales precoces de la maladie d'Alzheimer. Monatsschrift für Psychiatrie und Neurologie 1940; 102: 249-301.

6. Bootman MD, Thomas D, Tovey SC, Berridge MJ, Lipp P. Nuclear calcium signalling. Cell Mol Life Sci 2000; 57: 371-378.

7. Brockhaus J, Deitmer JW. Long-lasting modulation of synaptic input to Purkinje neurons by Bergmann glia stimulation in rat brain slices. Physiol 2002; 545 (Pt 2): 581-593.

8. Broe M, Kril J, Halliday GM. Astrocytic degeneration relates to the severity of disease in frontotemporal dementia. Brain 2004; 127 (Pt 10): 2214-20.

9. Cui W, Allen ND, Skynner M, Gusterson B, Clark AJ. Inducible ablation of astrocytes shows that these cells are required for neuronal survival in the adult brain. Glia 2001; 34: 272-282.

10. Diño MR, Schuerger RJ, Liu Y, Slater NT, Mugnaini E. Unipolar brush cell: a potential feedforward excitatory interneuron of the cerebellum. Neuroscience 2000; 98: 625-637.

11. Dolan RJ. A cognitive affective role for the cerebellum. Brain 1998; 121: 545-546.

12. Dymecki J, Kulczycki J. Neuropatologia. Urban \& Partner. Wrocław 2005, pp. 59-275

13. Floris A, Diño M, Jacobowitz DM, Mugnaini E. The unipolar brush cells of the rat cerebellar cortex and cochlear nucleus are calretinin-positive: a study by light and electron microscopic immunocytochemistry. Anat Embryol (Berl) 1994; 189: 495-520.

14. Freedman R, Hoffer BJ, Puro D, Woodward DJ. Noradrenaline mod ulation of the responses of the cerebellar Purkinje cell to afferent synaptic activity. Br J Pharmacol 1976; 57: 603-605.
15. Graham NI, Bak TH, Hodges JR. Corticobasal degeneration as a cognitive disorder. Mov Disord 2003; 18: 1224-1232.

16. Grosche J, Kettenmann H, Reichenbach A. Bergmann glial cells form distinct morphological structures to interact with cerebellar neurons. J Neurosci Res 2002; 68: 138-149.

17. Guo Q, Christakos S, Robinson N, Mattson MP. Calbindin D28k blocks the proapoptotic actions of mutant presenilin 1: reduced oxidative stress and preserved mitochondrial function. Proc Natl Acad Sci U S A 1998; 95: 3227-3232.

18. Hartmann J, Konnerth A. Determinants of postsynaptic Ca ${ }^{2+}$ signaling in Purkinje neurons. Cell Calcium 2005; 37: 459-466.

19. Iacopino AM, Christakos S. Specific reduction of calcium-binding protein (28-kilodalton calbindin-D) gene expression in aging and neurodegenerative diseases. Proc Natl Acad Sci U S A 1990; 87: 4078-4082.

20. Jaarsma D, Diño MR, Ohishi H, Shigemoto R, Mugnaini E. Metabotropic receptors are associated with non-synaptic appendages of unipolar brush cells in rat cerebellar cortex and cochlear nuclear complex. J Neurocytol 1998; 27: 303-327.

21. Kawaguchi SY, Hirano T. Signaling cascade regulating long-term potentiation of GABA $(A)$ receptor responsiveness in cerebellar Purkinje neurons. J Neurosci 2002; 22: 3969-3976.

22. Kerr CW, Bishop GA. Topographical organization in the origin of serotoninergic projections to different of the cat cerebellar cortex. J Comp Neurol 1991; 304: 502-515.

23. Kerr CW, Bishop GA. The physiological effects of serotonin are mediated by the $5 \mathrm{HT} 1 \mathrm{~A}$ receptor in the cat's cerebellar cortex. Brain Res 1992; 591: 253-260.

24. Kersaitis C, Halliday GM, Kril JJ. Regional and cellular pathology in frontotemporal dementia: relationship to stage of disease in cases with and without Pick bodies. Acta Neuropathol 2004; 108: 515-523.

25. Khachaturian ZS. Calcium hypothesis of Alzheimer's disease and brain aging. Ann N Y Acad Sci 1994; 747: 1-11.

26. Kimoto Y, Satoh K, Sakumoto T, Tohyama M, Shimizu N. Afferent fiber connections from the lower brain stem to the rat cerebellum by the horseradish peroxidase method combined with MAO staining, with special reference to noradrenergic neurons. J Hirnforsch 1978; 19: 85-100.

27. Klostermann O, Wahle P. Patterns of spontaneous activity and morphology of interneuron types in organotypic cortex and thalamuscortex cultures. Neuroscience 1999; 92: 1243-1259.

28. Kozubski W. Zaburzenia w obrębie układu nerwowego związane ze spożywaniem alkoholu. Przew Lek 2002; 5: 17-26.

29. Kwong WH, Chan WY, Lee KK, Fan M, Yew DT. Neurotransmitters, neuropeptides and calcium binding proteins in developing human cerebellum: a review. Histochem J 2000; 32: 521-534. Review.

30. Lainé J, Axelrad H. Extending the cerebellar Lugaro cell class. Neuroscience 2002; 115: 363-374.

31. Laure-Kamionowska M, Maślińska D. Calbindin positive Purkinje cells in the pathology of human cerebellum occurring at the time of its development. Folia Neuropathol 2009; 47: 300-305.

32. Laure-Kamionowska M, Maślińska D. Cerebellar cortical neurons misplaced in the white matter due to disturbed migration during development of human brain. Folia Neuropathol 2011; 49: 282-294.

33. Lippman JJ, Lordkipanidze T, Buell ME, Yoon SO, Dunaevsky A. Morphogenesis and regulation of Bergmann glial processes during 
Purkinje cell dendritic spine ensheathment and synaptogenesis. Glia 2008; 56: 1463-1477.

34. Maura G, Ricchetti A, Raiteri M. Serotonin inhibits the depolarization-evoked release of endogenous glutamate from rat cerebellar nerve endings. Neurosci Lett 1986; 67: 218-222.

35. Melik-Musian AB, Fanardzhian VV. Morphological characteristics of Lugaro cells of the cerebellar cortex. Morfologiia 2003; 123: 42-47.

36. Metea MR, Newman EA. Calcium signaling in specialized glial cells. Glia 2006; 54: 650-655.

37. Nagele RG, D'Andrea MR, Lee H, Venkataraman V, Wang HY. Astrocytes accumulate A beta 42 and give rise to astrocytic amyloid plaques in Alzheimer disease brains. Brain Res 2003; 971: 197-209.

38. Nowacki P. Neuropatologiczne podłoże zespołów paranowotworowych. Polski Przegląd Neurologiczny 2008; 4: 168-173.

39. Palay SL, Chan-Palay V. Cerebellar Cortex. Cytology and organization. Springer-Verlag, Berlin 1974.

40. Palczewska M, Groves P, Ambrus A, Kaleta A, Kövér KE, Batta G, Kuźnicki J. Structural and biochemical characterization of neuronal calretin domain I-II (residues 1-100). Comparison to homologous calbindin D28k domain I-II (residues 1-93). Eur J Biochem 2001; 268: 6229-6237.

41. Résibois A, Rogers JH. Calretin in rat brain: an immunohistochemical study. Neuroscience 1992; 46: 101-134.

42. Rodríguez JJ, Olabarria M, Chvatal A, Verkhratsky A. Astroglia in dementia and Alzheimer's disease. Cell Death Differ 2009; 16: 378-385.

43. Rosenberg PA, Aizenman E. Hundred-fold increase in neuronal vulnerability to glutamate toxicity in astrocyte-poor cultures of rat cerebral cortex. Neurosci Lett 1989; 103: 162-168.

44. Rosenberg PA. Accumulation of extracellular glutamate and neuronal death in astrocyte-poor cortical cultures exposed to glutamine. Glia 1991; 4: 91-100.

45. Rothstein JD, Martin L, Levey Al, Dykes-Hoberg M, Jin L, Wu D, Nash N, Kuncl RW. Localization of neuronal and glial glutamate transporters. Neuron 1994; 13: 713-725.

46. Schiffmann SN, Cheron G, Lohof A, d'Alcantara P, Meyer M, Parmentier M, Schurmans S. Impaired motor coordination and Purkinje cell excitability in mice lacking calretin. Proc Natl Acad Sci U S A 1999; 96: 5257-5262.

47. Schmahmann JD, Sherman JC. The cerebellar cognitive affective syndrome. Brain 1998; 121 (Pt 4): 561-579.

48. Schmahmann JD. From movement to thought: anatomic substrates of the cerebellar contribution to cognitive processing. Hum Brain Mapp 1996; 4: 174-198.

49. Sjöbeck M, Englund E. Alzheimer's disease and the cerebellum: a morphologic study on neuronal and glial changes. Dement Geriatr Cogn Disord 2001; 12: 211-218.

50. Storck T, Schulte S, Hofmann K, Stoffel W. Structure, expression, and functional analysis of a $\mathrm{Na}$ (1)-dependent glutamate/aspartate transporter from rat brain. Proc Natl Acad Sci USA 1992; 89: 10955-10959.

51. Sugiyama K, Brunori A, Mayer ML Glial uptake of excitatory amino acids influences neuronal survival in cultures of mouse hippocampus. Neuroscience 1989; 32: 779-791.

52. Tanaka M, Maeda N, Noda M, Marunouchi T. A chondroitin sulfate proteoglycan PTPzeta/RPTPbeta regulates the morphogenesis of Purkinje cell dendrites in the developing cerebellum. J Neurosci 2003; 23: 2804-2814.

53. Watase K, Hashimoto K, Kano M, Yamada K, Watanabe M, Inoue Y, Okuyama S, Sakagawa T, Ogawa S, Kawashima N, Hori S, Takimoto M, Wada K, Tanaka K. Motor discoordination and increased susceptibility to cerebellar injury in GLAST mutant mice. Eur J Neurosci 1998; 10: 976-988.

54. Wegiel J, Wisniewski HM, Dziewiatkowski J, Badmajew E, Tarnawski M, Reisberg B, Mlodzik B, De Leon MJ, Miller DC. Cerebellar atrophy in Alzheimer's disease-clinicopathological correlations. Brain Res 1999; 818: 41-50.

55. Wierzba-Bobrowicz T, Lewandowska E, Stępień T, Szpak GM. Differential expression of calbindin D28k, calretin and parvalbumin in the cerebellum of pups of ethanol-treated female rats. Folia Neuropathol 2011; 49: 47-55.

56. Zabłocka A. Alzheimer's disease as neurodegenerative disorder. Postepy Hig Med Dosw (online) 2006; 60: 209-216. Review [Polish]. 